\title{
Meta-Analysis: The Relationship of Fe Tablet Consumption Adherence and Anemia Prevalence in Pregnant Women
}

\author{
Muti'ah Ma'rifati Ilma', Roselina Panghiyangani ${ }^{2}$, Nia Kania ${ }^{2}$, Husaini', \\ Meitria Syahadatina Noor ${ }^{2}$ \\ ${ }^{1}$ Master of Public Health Science Study Program \\ ${ }^{2}$ Faculty of Medicine, Lambung Mangkurat University, Indonesia \\ Corresponding Author: Muti'ah Ma'rifati Ilma
}

\begin{abstract}
Anemia in pregnancy is anemia due to iron deficiency. The incidence of anemia in pregnant women ranges from $20 \%$ to $89 \%$. As many as $40 \%$ of maternal deaths in developing countries are related to anemia in pregnancy and most often occur in developing countries, including Indonesia. In Indonesia, efforts made to overcome the problem of anemia in pregnant women are the administration of iron $(\mathrm{Fe})$ tablets. This study aims to explain and analyse the relationship of adherence to $\mathrm{Fe}$ tablet consumption with anemia in pregnant women. This study uses a meta-analysis study. Researchers carried out research data collection by browsing online journals, using the Scopus and Google Scholar databases. In the meta-analysis process using the RevMan (Review Manager) 5.3 application, the results obtained Effect size (In Odds Ratio) of 2.44 (95\% CI 1.30-4.60), which means that pregnant women who do not adhere to consuming $\mathrm{Fe}$ tablets have a risk 2.44 times affected by anemia compared to obedient pregnant women. There is a significant relationship between consuming $\mathrm{Fe}$ tablets and the incidence of anemia in pregnant women.
\end{abstract}

Keywords: adherence, Fe tablets, anemia

\section{INTRODUCTION}

Anemia is when the number of red blood cells (erythrocytes) is lower than normal, which is usually measured as a decrease in the concentration of hemoglobin
$(\mathrm{Hb})$. Red blood cells in the blood contain hemoglobin which functions to carry oxygen to all body tissues (Hackley et al, 2013; Proverawati, 2013; Tarwoto \& Wasnidar, 2007; Sudasiyah, 2017).

Anemia in pregnancy is anemia due to iron deficiency, according to WHO the incidence of anemia in pregnancy ranges from 20\% to 89\% (Manuaba, 2010; Prawirohardjo, 2016). Anemia contributes to maternal mortality in Indonesia, estimated at $10 \%$ to $12 \%$. Where it means that $10 \%$ to $12 \%$ of maternal deaths in Indonesia can be prevented if the incidence of anemia in pregnant women can be reduced to the lowest possible (Novitayanti, et al, 2020)

Based on the World Health Organization (WHO, 2015), the prevalence of anemia in pregnant women in the world is around $40.1 \%$. This percentage has increased from $39.8 \%$ in 2015 and $39.6 \%$ in 2014. The prevalence of anemia in pregnant women is estimated at $48.2 \%$ in Asia, $57.1 \%$ in Africa, $24.1 \%$ in America and $25.1 \%$ in Europe (Astriana, 2017). The World Health Organization (WHO) reports that $52 \%$ of pregnant women experience anemia in developing countries (WHO, 2015; Romlah \& Anjelina, 2020).

Anemia in pregnancy can cause the risk of complications during pregnancy, childbirth and puerperium. Various complications occur due to anemia, such as 
prolonged labor due to uterine inertia, postpartum hemorrhage due to uterine atony, shock, and infection (intrapartum and postpartum). In addition, disturbances or obstacles to the growth of body cells and brain cells in the fetus, miscarriage, premature birth, low birth weight babies, bleeding can occur due to iron $(\mathrm{Fe})$ deficiency experienced by pregnant women. Even maternal and infant mortality is a risk faced by pregnant women who experience severe anemia (Ministry of Health RI, 2009; Guyton \& Hall, 2011; Sari \& Romlah, 2019).

Based on data from Riskesdas (2010), the incidence of anemia is still quite high, namely, 50-70 million people, iron deficiency anemia (anemia caused by lack of iron) reaches 20\%-33\%. As much as $40.1 \%$ anemia experienced by pregnant women with a lower limit of $11 \mathrm{~g} / \mathrm{dl}(\mathrm{MoH}$, 2011). Riskesdas data (2018) the prevalence of iron nutritional anemia in pregnant women in Indonesia in 2013 was $37.1 \%$ and increased in 2018 to $48.9 \%$.

The World Health Organization recommends giving iron $(\mathrm{Fe})$ tablet supplementation to pregnant women. Because during pregnancy, the need for iron during pregnancy cannot be met only from food. Pregnant women are highly recommended to take 90 tablets of iron $(\mathrm{Fe})$ during pregnancy which must be taken daily (Khomsan, 2004 and Darwanty, 2018).

In Indonesia, the effort that has been made to overcome the problem of anemia in pregnant women is the administration of iron $(\mathrm{Fe})$ tablets. Nationally, based on Riskesdas (2018) data, 38.1\% of pregnant women who consume iron $(\mathrm{Fe})$ tablets 90 tablets. Compliance with consuming iron (Fe) tablets can be interpreted that the pregnant woman likes to obey orders, obey orders, rules from health workers in taking iron $(\mathrm{Fe})$ tablets. Therefore, compliance with consuming iron $(\mathrm{Fe})$ tablets is an attitude taken by pregnant women following the recommendations and instructions of medical officers in consuming iron $(\mathrm{Fe})$ tablets (Obai, et al, 2016). Therefore, maternal compliance plays a very important role in increasing $\mathrm{Hb}$ levels. (Depkes RI 2007; Manuaba, 2010; Fakhriyah et al, 2018)

Based on the results of research conducted by Amanupunnyo (2018), Chalik (2019), Desi (2015), Fitri (2015), Katmini (2020), Miarti (2020), Sepduwiana (2017), Sukmawati (2020), Triyani (2016), Utomo (2015) and Yanti (2016) and it was found that there is a relationship between adherence to Fe tablet consumption and the incidence of anemia in pregnant women. This is in line with the results of Ariyani (2018) and Fakhriyah (2018) research that adherence to consuming $\mathrm{Fe}$ tablets is a factor that affects the highest incidence of anemia in pregnant women, which is $60 \%$ compared to other factors. Furthermore, the non-compliance of pregnant women in consuming Fe tablets has 6 times the risk of developing anemia than pregnant women who obediently consume Fe tablets.

The higher the compliance of pregnant women in consuming iron $(\mathrm{Fe})$ tablets, the higher the $\mathrm{Hb}$ levels of the pregnant women. Anemia that occurs due to non-compliance in consuming iron $(\mathrm{Fe})$ tablets is caused by feeling lazy, bored, the assumption that iron $(\mathrm{Fe})$ tablets are not important, forgetting to the side effects of iron $(\mathrm{Fe})$ tablets that make you uncomfortable, such as nausea., vomiting, smelly and unpleasant (Nugroho, et.al, 2017)

Pregnant women who are not obedient in consuming iron tablets cannot meet iron needs in pregnancy. As a result, the risk of anemia in pregnancy, especially iron-deficiency anemia, increases (Malah, et al, 2016). Conversely, the more obedient pregnant women consume iron tablets given by health workers, the smaller the chance of anemia (Sophia, 2009 and Ratnasari, 2017).

Based on Tanziha (2016) research, Sinaga (2019) said no relationship between adherence to Fe tablet consumption and the incidence of anemia in pregnant women. This is probably due to consuming iron tablets and inhibitors in pregnant women 
who consume high iron tablets. Zijp et al. (2000) revealed that consumption of iron sources and tea consumption causes $60 \%$ absorption of iron intake to be inhibited. Based on this background, the authors are interested in analysing the relationship between $\mathrm{Fe}$ tablet consumption and the incidence of anemia in pregnant women.

\section{MATERIALS \& METHODS}

Research design used in this study was meta-analysis study. The reference used to formulate research questions is "SPIDER". The identification in this study are as follows:

a. $\mathrm{S}$ for the sample in this study, the sample is pregnant women. b. P and I for Phenomenon of Interest, which is the interest in the event or phenomenon, is how and why the behaviour of pregnant women in compliance with Fe tablet consumption with the incidence of anemia in pregnant women.

c. D for Design, the research design used is a quantitative study with a crosssectional type of research.

d. E for Evaluation, the evaluation of this study is the relationship between adherence to consumption of Fe tablets with the incidence of anemia in pregnant women.

e. $\mathrm{R}$ is for Research type, this type of research is quantitative research.

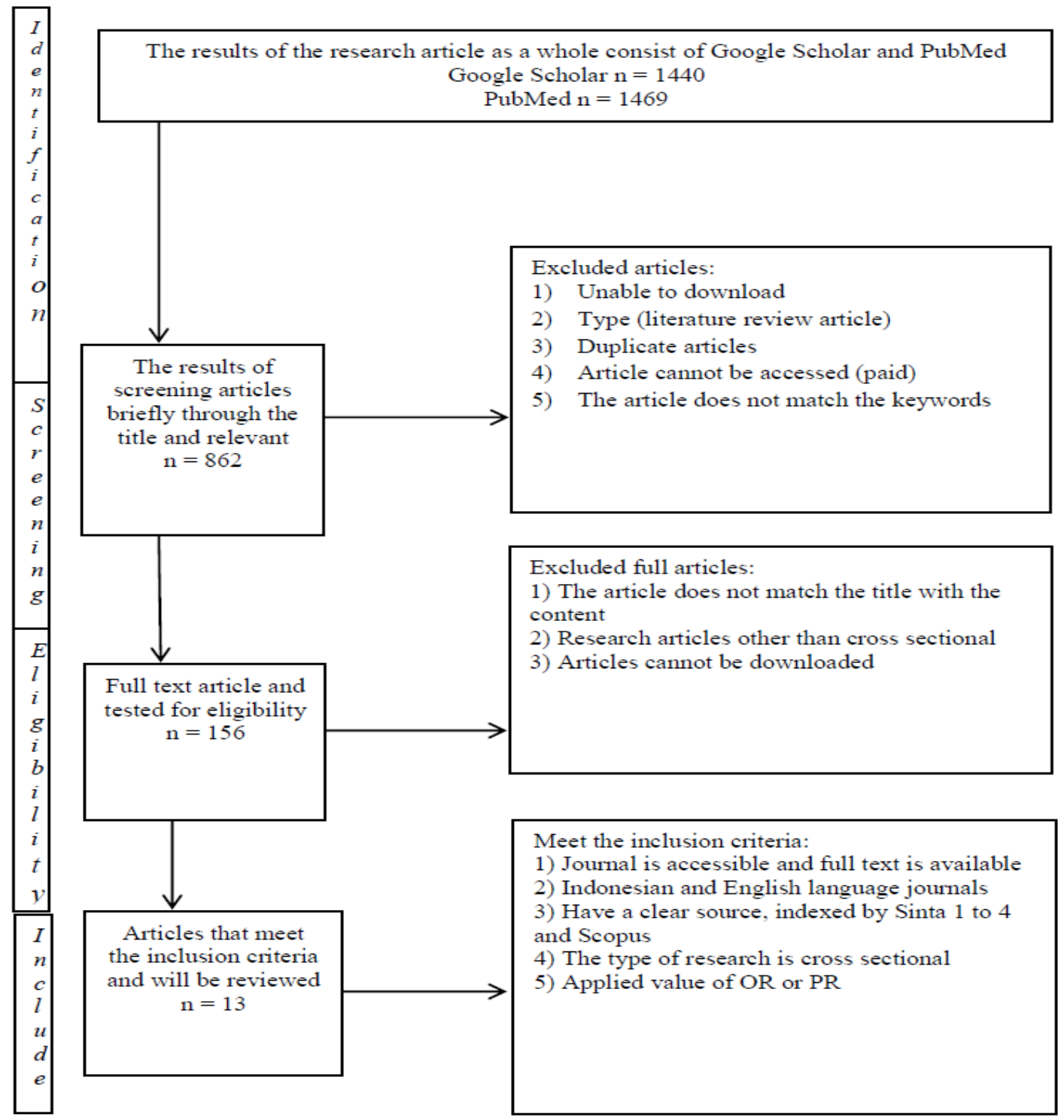

Figure 1: Flow Chart PRISMA of the Research 


\section{RESULT}

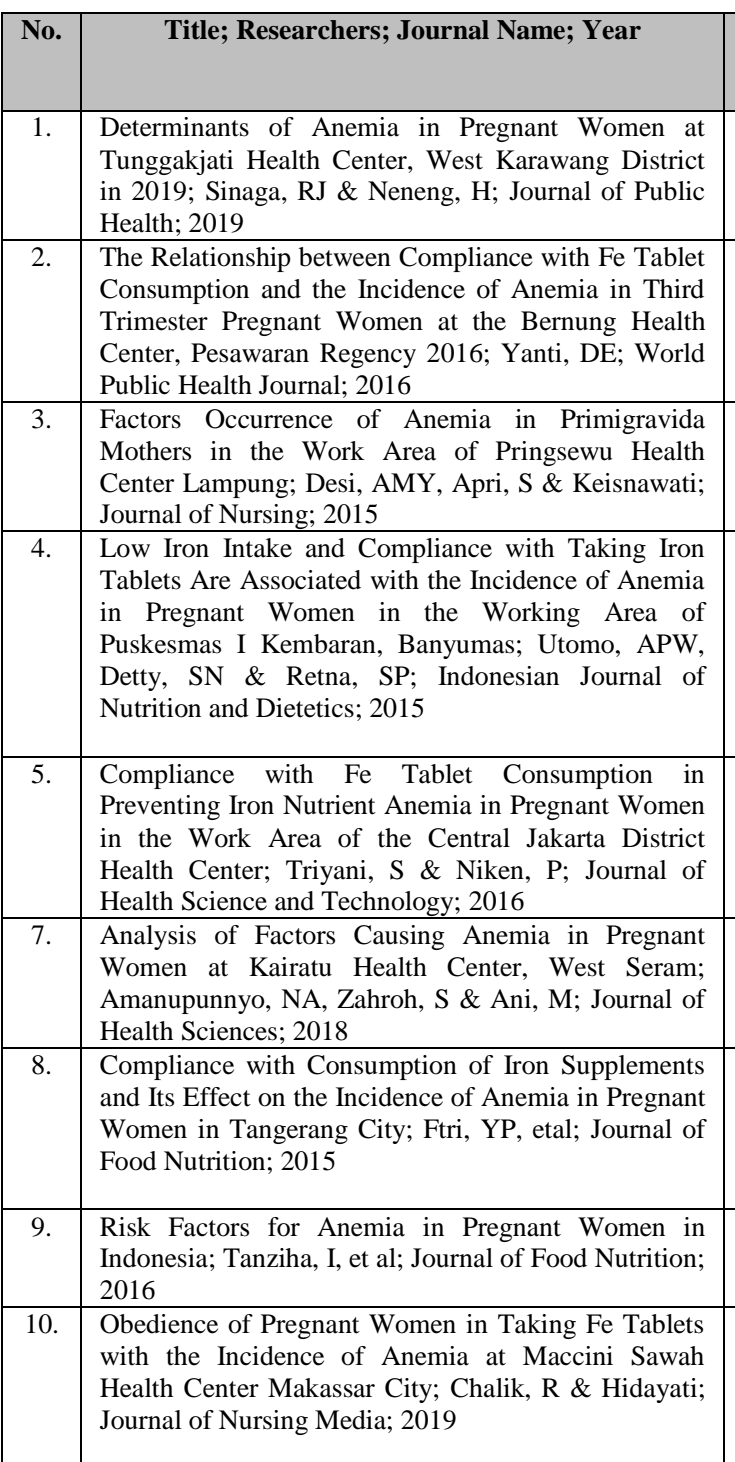

Table 1: List and details of articles under meta-analysis in this study

\begin{tabular}{|c|c|c|c|c|c|c|}
\hline Location & Research purposes & $\begin{array}{c}\text { Research } \\
\text { design }\end{array}$ & $\begin{array}{l}\text { Number of } \\
\text { Respondents }\end{array}$ & $\begin{array}{l}\text { Measurement } \\
\text { Method }\end{array}$ & $\begin{array}{ll}\text { Data } & \text { analysis } \\
\text { technique } & \end{array}$ & $\begin{array}{l}\text { Result } \\
\text { (OR/ } \\
\text { PR) }\end{array}$ \\
\hline $\begin{array}{l}\text { Tunggakjati } \\
\text { Health Center, } \\
\text { West Karawang } \\
\text { District } \\
\end{array}$ & $\begin{array}{l}\text { Factors related to the incidence of } \\
\text { anemia in pregnant women }\end{array}$ & $\begin{array}{c}\text { Cross- } \\
\text { sectional }\end{array}$ & 70 & Questionnaire & Chi-square & $\begin{array}{c}\mathrm{OR}=0.961 \\
(0.674-1.370)\end{array}$ \\
\hline $\begin{array}{l}\text { Bernung Health } \\
\text { Center, } \\
\text { Pesawaran } \\
\text { Regency }\end{array}$ & $\begin{array}{l}\text { It is known that there is a } \\
\text { relationship between compliance } \\
\text { with Fe tablet consumption and the } \\
\text { incidence of anemia in pregnant } \\
\text { women }\end{array}$ & $\begin{array}{c}\text { Cross- } \\
\text { sectional }\end{array}$ & 87 & Checklist & $\begin{array}{l}\text { Chi-square and logistic } \\
\text { regression }\end{array}$ & $\mathrm{OR}=5.35$ \\
\hline $\begin{array}{l}\text { Pringsewu } \\
\text { Health Center } \\
\text { Lampung }\end{array}$ & $\begin{array}{l}\text { Knowing the factors of anemia in } \\
\text { pregnant women }\end{array}$ & $\begin{array}{c}\text { Cross- } \\
\text { sectional }\end{array}$ & 168 & Secondary data & Chi-square & $\begin{array}{c}\mathrm{OR}=6.283 \\
(3.122-12.544)\end{array}$ \\
\hline $\begin{array}{ll}\text { Puskesmas } & \text { I } \\
\text { Kembaran, } \\
\text { Banyumas } \\
\text { Regency }\end{array}$ & $\begin{array}{l}\text { Knowing the relationship between } \\
\text { nutrient intake and the level of } \\
\text { adherence to consuming iron } \\
\text { tablets with the incidence of } \\
\text { anemia in pregnant women in the } \\
\text { Working Area of Puskesmas I } \\
\text { Kembaran, Banyumas Regency }\end{array}$ & $\begin{array}{c}\text { Cross- } \\
\text { sectional }\end{array}$ & 50 & Questionnaire & Chi-square & $\begin{array}{c}\mathrm{PR}=3.75 \\
(2.07-6.78)\end{array}$ \\
\hline $\begin{array}{lc}\text { Central } & \text { Jakarta } \\
\text { District } & \text { Health } \\
\text { Center } & \end{array}$ & $\begin{array}{l}\text { The purpose of this study was to } \\
\text { determine the relationship between } \\
\text { adherence to Fe tablet consumption } \\
\text { and anemia status of pregnant } \\
\text { women }\end{array}$ & $\begin{array}{l}\text { Cross- } \\
\text { sectional }\end{array}$ & 134 & Questionnaire & Chi-square & $\begin{array}{c}\mathrm{OR}=5.985 \\
(0.905-28.320)\end{array}$ \\
\hline $\begin{array}{ll}\text { West } & \text { Seram } \\
\text { Kairatu } & \text { Health } \\
\text { Center } & \end{array}$ & $\begin{array}{l}\text { To identify the factors that cause } \\
\text { anemia in pregnant women at the } \\
\text { Kairatu Public Health Center }\end{array}$ & $\begin{array}{c}\text { Cross- } \\
\text { sectional }\end{array}$ & 120 & $\begin{array}{l}\text { View live and } \\
\text { secondary data }\end{array}$ & $\begin{array}{l}\text { Chi-square and logistic } \\
\text { regression }\end{array}$ & $\begin{array}{c}\mathrm{OR}=17.763 \\
(1.968-160.347)\end{array}$ \\
\hline Tangerang City & $\begin{array}{l}\text { To analyse adherence to iron } \\
\text { supplement consumption and } \\
\text { its effect on the incidence of } \\
\text { anemia in pregnant women in } \\
\text { Tangerang City }\end{array}$ & $\begin{array}{c}\text { Cross- } \\
\text { sectional }\end{array}$ & 91 & Questionnaire & Chi-square & $\begin{array}{c}\mathrm{OR}=4.250 \\
(1.425-12.671)\end{array}$ \\
\hline Indonesia & $\begin{array}{l}\text { Analysing risk factors for anemia } \\
\text { in pregnant women in Indonesia }\end{array}$ & $\begin{array}{c}\text { Cross- } \\
\text { sectional }\end{array}$ & 452 & Secondary data & $\begin{array}{l}\text { Chi-square and logistic } \\
\text { regression }\end{array}$ & $\begin{array}{c}\mathrm{OR}=0.721 \\
(0.461-1.128)\end{array}$ \\
\hline $\begin{array}{l}\text { Maccini } \\
\text { Health Cawah } \\
\text { Makassar }\end{array}$ & $\begin{array}{l}\text { This study aims to determine the } \\
\text { relationship between pregnant } \\
\text { women's compliance in taking Fe } \\
\text { tablets with the incidence of } \\
\text { anemia }\end{array}$ & $\begin{array}{l}\text { Cross- } \\
\text { sectional }\end{array}$ & 93 & $\begin{array}{l}\text { Observation } \\
\text { sheet and } \\
\text { questionnaire }\end{array}$ & $\begin{array}{l}\text { Chi-square and logistic } \\
\text { regression }\end{array}$ & $\begin{array}{c}\mathrm{OR}=5.096 \\
(1.459-17.803)\end{array}$ \\
\hline
\end{tabular}




\begin{tabular}{|c|c|c|c|c|c|c|c|c|}
\hline \multicolumn{9}{|c|}{ Table no 1: continued... } \\
\hline 11. & $\begin{array}{l}\text { Relationship between Pregnancy Distance and } \\
\text { Compliance with Table Fe Consumption with Anemia } \\
\text { Incidence in Pregnant Women in the Work Area of } \\
\text { Rambah Samo Health Center 1; Sepduwiana, H \& } \\
\text { Ratih, NSS; Journal of Martenity and Neonatal; } 2017\end{array}$ & $\begin{array}{l}\text { Rambah Samo } \\
\text { Health Center } 1\end{array}$ & $\begin{array}{l}\text { To determine the distance between } \\
\text { pregnancy and adherence to } \\
\text { consuming } \mathrm{Fe} \text { tablets with the } \\
\text { incidence of anemia in pregnant } \\
\text { women }\end{array}$ & $\begin{array}{c}\text { Cross } \\
\text { sectional }\end{array}$ & 66 & Questionnaire & Chi square & $\begin{array}{c}\mathrm{OR}=0.462 \\
(0.344-0.619)\end{array}$ \\
\hline 12. & $\begin{array}{l}\text { Pregnancy Anemia And Its Affecting Factors: } \\
\text { Correlation Study; Sukmawati, et al; Journal of } \\
\text { Health Bakti Husada:Journal of Nursing, Health } \\
\text { Analyst and Pharmacy;2020 }\end{array}$ & $\begin{array}{l}\text { Hauranggung } \\
\text { Health Center, } \\
\text { Garut Regency }\end{array}$ & $\begin{array}{l}\text { To analyse the factors associated } \\
\text { with the incidence of anemia in } \\
\text { pregnant women at the } \\
\text { Haurpanggang Health Center }\end{array}$ & $\begin{array}{c}\text { Cross- } \\
\text { sectional }\end{array}$ & 70 & Questionnaire & Chi-square & $\begin{array}{c}\mathrm{OR}=0.317 \\
(0.116-0.862)\end{array}$ \\
\hline 13. & $\begin{array}{l}\text { Factors Associated with Anemia among in Pregnant } \\
\text { Women in Trimester III; Katmini \& Astri, Y; Journal } \\
\text { of Maternal and Child Health;2020 }\end{array}$ & $\begin{array}{l}\text { Pesantren I } \\
\text { Health Center in } \\
\text { Kediri City }\end{array}$ & $\begin{array}{l}\text { To determine the factors associated } \\
\text { with anemia in pregnancy }\end{array}$ & $\begin{array}{c}\text { Cross- } \\
\text { sectional }\end{array}$ & 33 & Questionnaire & Chi-square & $\begin{array}{c}\mathrm{OR}=5.50 \\
(1.14-2.64)\end{array}$ \\
\hline
\end{tabular}

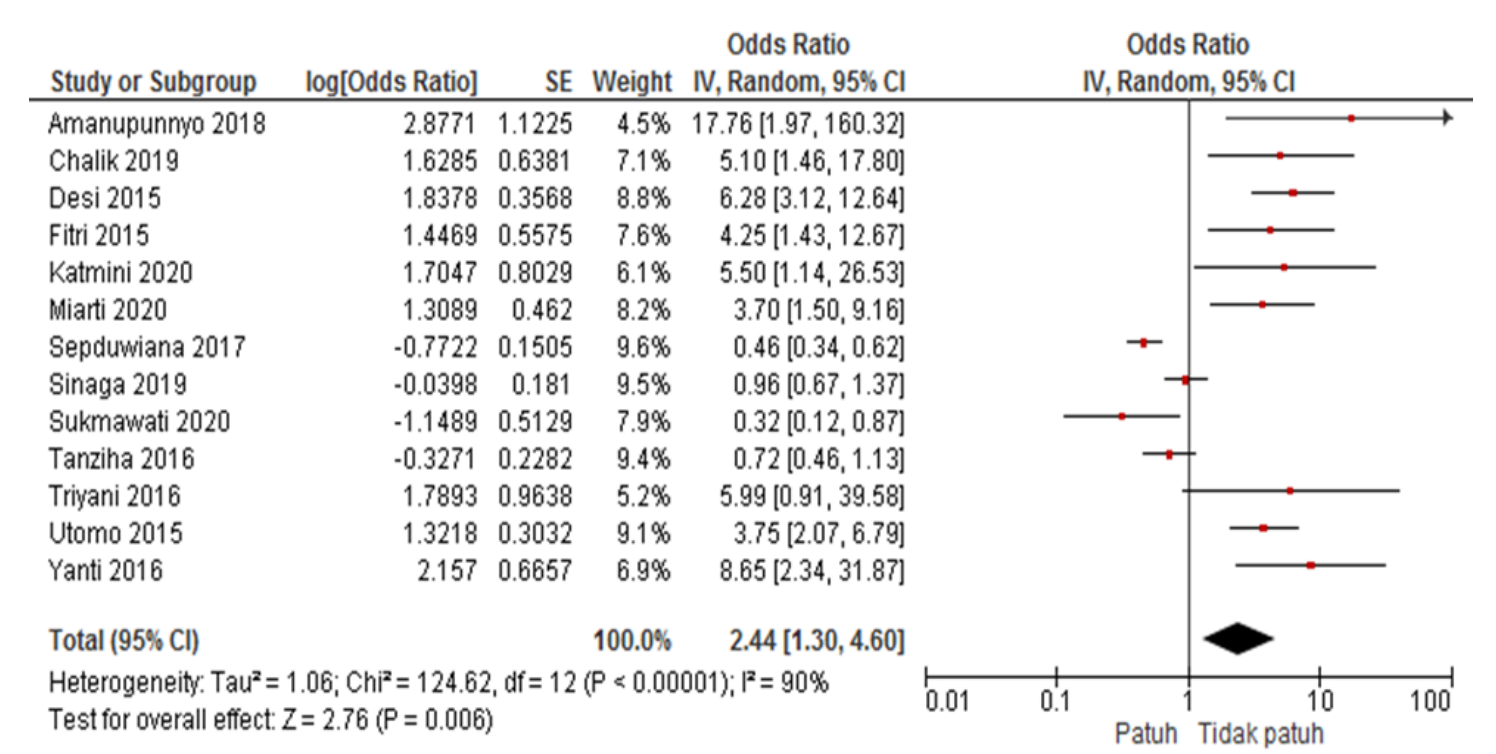

Figure 2: Forest plot of the relationship of adherence to Fe tablet consumption with the incidence of anemia in pregnant women 
Based on Figure 2 above shows that the variation between the studies analysed is heterogeneous. The p-value evidence this in the heterogeneity test, which is less than 0.05 , namely $\mathrm{P}=0.00001$, and the $\mathrm{I}^{2}$ value is more than $50 \%$, namely $\mathrm{I} 2=90 \%$. The value of Tau 2 on heterogeneity shows the observed effect size if the value of Tau2>0 means the study is heterogeneous. In this study, the value of Tau2=1.06, which means that this study is heterogeneous. So in this analysis, using a random-effect model. The $\mathrm{Z}$-value indicates the combined or overall effect on the analysed articles (test for overall effect) is 2.76 and with a p-value of 0.006. In this study, it can be seen that the value of the weight or strength of each article/journal is good, with the lowest score being 4.5 and the highest being 9.6. Meanwhile, the SE (Standard Error) values in the analysed studies or articles/journals ranged from the lowest with a value of 0.1505 and the highest with 1.1225.

The results of the Forest plot test above show that the pooled odds ratio or the overall Odds Ratio value obtained is 2.44 (95\% CI 1.30-4.60). So it can be concluded that pregnant women who do not comply have a 2.44 times risk of developing anemia. With the combined effect value $(\mathrm{Z})$ of 2.76 and the value of $\mathrm{P}=0.006$. Statistically, the combined effect was significant if the $\mathrm{p}$-value $<0.05$, which means a significant relationship between adherence to Fe tablet consumption and the incidence of anemia in pregnant women.

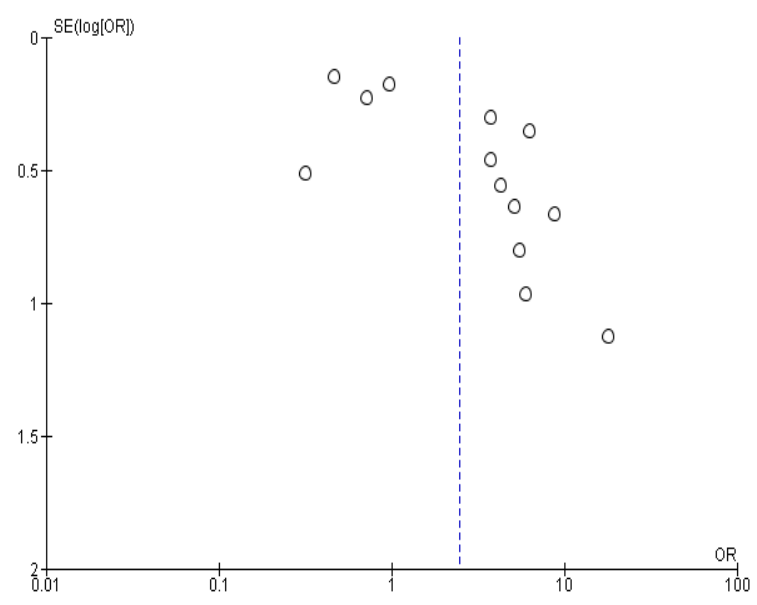

Figure 3: Funnel Plot Graphic
Based on the results of the analysis in Figure 3, it can be seen that the circles contained in the funnel plot graph depicting the analysed articles are not symmetrical between the 4 quadrants, namely the left (top and bottom) and right (top and bottom). So it can be concluded that this research is publication bias. This may be due to the unequal number of large and small samples in the analysed articles, causing bias.

Based on Figure 3, it can be seen that the inequality in the number of large and small samples in this study. Seen at the bottom left and right of the funnel plot looks empty. This means that there is no small sample size in this study. The number of samples in this study ranged from 168-33, and there was only one study with a sample size of 452. Therefore, the number of samples is still quite large, causing the small sample size to be empty in the funnel plot.

\section{DISCUSSION}

Research

conducted by

Amanupunnyo (2018) shows that there is a relationship between compliance with the incidence of anemia in pregnant women, with an OR value $=17.76$ (1.97-160.32), which means that pregnant women who do not comply with taking Fe tablets during pregnancy are at risk of 17.76 times more likely to suffer from anemia compared to pregnant women who obediently consume Fe tablets during pregnancy. Thus, the number of pregnant women who do not comply with taking $\mathrm{Fe}$ tablets during pregnancy is due to the lack of knowledge of pregnant women about the benefits of $\mathrm{Fe}$ tablets and anemia in pregnancy.

This is in line with research conducted by Desi (2015) with an OR value of 6.28 (3.12-12.64), Katmini (2020) with an OR value of $5.50(1.14-26.53)$ and Triyani (2016) with OR=5.99 (0.91-39.58). The three studies show a relationship between adherence to Fe tablet consumption and the incidence of anemia in pregnant women. Pregnant women who do not comply with taking Fe tablets are pregnant 
women who have poor knowledge about consuming Fe tablets.

Based on the analysis results in this study, non-adherence to consuming $\mathrm{Fe}$ tablets during pregnancy is one of the factors causing anemia in pregnant women. During pregnancy, pregnant women are very susceptible to anemia because pregnant women experience blood thinning or hemodilution during pregnancy. Therefore, consumption of $\mathrm{Fe}$ tablets during pregnancy is very important for pregnant women to prevent anemia in pregnancy.

Providing information and education about the consumption of $\mathrm{Fe}$ tablets and anemia in pregnancy is very important to pregnant women to improve the behavior of pregnant women in consuming $\mathrm{Fe}$ tablets during pregnancy. Therefore, there is a need for health education about anemia in pregnant women and its prevention continuously and continuously, using various media.

Knowledge of pregnant women about anemia, food sources of iron and the need to take Fe tablets is relatively low. To anticipate the factors that underlie the emergence of knowledge, attitudes and behavior problems in pregnant women, providing information and education is an activity that must be done to overcome anemia in pregnant women (Notoatmojo, 2016). A good proportion of knowledge will increase pregnant women's compliance in consuming Fe tablets, so that the prevalence of anemia can decrease. Compliance with consuming Fe tablets is a form of behavior that can be realised due to knowledge gained from outside as well as beliefs and encouragement from others such as health workers, neighbours or close friends (Green, 2015).

In a study conducted by Chalik (2019) there was a relationship between adherence to consuming $\mathrm{Fe}$ tablets and the incidence of anemia in pregnant women, with an OR value of 5.10 (1.46-17.80). This means that pregnant women who do not comply with taking Fe tablets have a 5.10 times risk of developing anemia when compared to pregnant women who obediently consume $\mathrm{Fe}$ tablets during pregnancy. The results of Utomo's research (2015) also found a significant relationship between adherence to Fe tablet consumption and the incidence of anemia in pregnant women. Pregnant women who do not comply with taking $\mathrm{Fe}$ tablets during pregnancy are caused by irregular consumption of Fe tablets, forgetting to take Fe tablets, refusing to take Fe tablets because tablets are difficult to swallow, because of the side effects of Fe tablets and lack of support from the family to encourage pregnant women to consume $\mathrm{Fe}$ tablets. Fe tablets (Chalik, 2019; Utomo, 2015).

The side effects of iron $(\mathrm{Fe})$ tablets are annoying so that pregnant women tend to refuse to take the given iron $(\mathrm{Fe})$ tablets, these side effects can be in the form of unpleasant effects such as a bad feeling in the pit of the stomach, nausea, vomiting and diarrhea. sometimes also constipation) this complication often reduces patient compliance during treatment. This refusal actually stems from their ignorance that they need additional iron (Arisman, 2010 and Ruwaydah \& Nurmisi, 2019).

Based on the analysis results in this study, although there are side effects from consuming Fe tablets, the level of adherence to Fe tablets needs to be increased because of the importance of $\mathrm{Fe}$ tablets during pregnancy. Therefore, it is necessary to have proper counselling so that pregnant women understand and understand the importance of $\mathrm{Fe}$ tablets. In addition, some pregnant women who feel the side effects of $\mathrm{Fe}$ tablets may be due to the wrong time of taking $\mathrm{Fe}$ tablets. For example, most pregnant women take $\mathrm{Fe}$ tablets in the morning, whereas $\mathrm{Fe}$ tablets are recommended to take them at night before going to bed to reduce the side effects of the Fe tablets themselves (Azam, 2012).

This is in line with Miarti (2020) research showing that there is a relationship between compliance with the incidence of anemia in pregnant women with $\mathrm{OR}=3.70$ 
(1.50-9.16). The behavior of pregnant women who do not obey the lack of knowledge of the function of $\mathrm{Fe}$ tablets. Most of the pregnant women who are not obedient in taking Fe tablets are related to the time of taking Fe tablets. Some pregnant women take $\mathrm{Fe}$ tablets in the morning (Anggraini, 2017). Based on statistical tests in Yanti's research (2016) there is a relationship between adherence to Fe tablet consumption and the incidence of anemia in pregnant women with an OR value of 8.65 (2.34-31.87), which means that pregnant women who do not comply with Fe tablets are at risk 8.65 times more anemia than pregnant women who obediently consume Fe tablets. Giving Fe tablets every day for pregnant women is a standard of government and WHO programs to prevent anemia. This is in line with Fitri's (2015) research on the importance of increasing adherence to $\mathrm{Fe}$ tablet consumption to prevent and control anemia. Pregnant women are advised to take Fe tablets at a dose of 2x1 (120 mg/day) (MoH RI, 2014).

Compliance with $\mathrm{Fe}$ tablet consumption was measured from the determination of the number of Fe tablets consumed, the accuracy of consuming $\mathrm{Fe}$ tablets, and the frequency of consumption of Fe tablets per day. Iron supplementation or administration of Fe tablets is an important effort in preventing and overcoming anemia, especially iron-deficiency anemia or iron deficiency. Giving Fe tablets is an effective way because of the iron content that is equipped with folic acid which can prevent anemia due to folic acid deficiency (Galloway, 2013).

However, the studies above contradict the research results conducted by Tanziha (2016) which states that there is no relationship between adherence to Fe tablet consumption and the incidence of anemia in pregnant women, with $\mathrm{OR}=0.72(0.46$ 1.13). This is probably due to the habit of consuming $\mathrm{Fe}$ tablets together with inhibitors in pregnant women who consume Fe tablets. Food sources of iron inhibitors are food sources that will inhibit the absorption of iron. Food sources which are iron inhibitors, come from food sources of tannins, phytates and calcium. For example, the tannins in tea and coffee are strong inhibitors of iron (Putri \& Sumarmi, 2013).

This is in line with research conducted by Zijp et al (2000) that consumption of iron sources along with tea consumption causes $60 \%$ absorption of iron intake to be inhibited. The results of this study are also in line with research conducted by Khambalia et al (2009) that iron supplementation in pregnant women does not reduce anemia (Zijp, et al. 2000; Khambalia, et al 2009).

Based on the results of research from Sinaga (2019), it was stated that there was no relationship between adherence to $\mathrm{Fe}$ tablet consumption and the incidence of anemia in pregnant women, with an OR value of $0.96(0.34-0.62)$. This is because it is not only $\mathrm{Fe}$ tablets that affect anemia status, but consumption patterns and nutritional intake of pregnant women also affect. A good diet for pregnant women must meet sources of carbohydrates, protein and fat, and vitamins and minerals that are adjusted to the needs during pregnancy (Bakta, 2007; Miarti, et al, 2020).

Diet for pregnant women concerns the type and amount of food, where the type and amount of food that must be met during pregnancy is rice/substitute $4-51 / 2$ plates, animal side dishes 4-5 pieces, vegetable side dishes 2-4 pieces, vegetables 2-3 a bowl, 3 pieces of fruit and drink no less than 8 glasses of water per day. Poor diet is one factor for anemia during pregnancy, especially due to lack of consumption of foods rich in iron. During pregnancy, iron deficiency often occurs, resulting in a decrease in $\mathrm{Hb}$ levels caused by hemodilution in the body of pregnant women and poor diet and consumption of foods containing iron (MoH RI, 2014).

The results of Ariyani's research (2016) showed that the factor that influenced the highest incidence of anemia was the compliance factor of pregnant women in consuming tablets, which was 
$60 \%$ compared to other factors (Ariyani, 2016 and Fakhriyah, et al 2018). Thus, it can be seen that there is a tendency that if pregnant women are obedient in taking $\mathrm{Fe}$ tablets, the possibility of pregnancy anemia is getting smaller (Fajrin, 2020).

According to Arisman (2010), anemia in pregnant women is mostly caused by iron deficiency, often known as iron deficiency anemia. One of the efforts to overcome iron deficiency anemia in pregnant women is by giving Fe tablets to pregnant women at least 90 tablets during pregnancy. However, this effort has not been maximised until now to reduce the incidence of anemia in pregnant women. One of the obstacles of this program is the lack of compliance of pregnant women in consuming $\mathrm{Fe}$ tablets during pregnancy (Wuwuh, 2016).

Based on the analysis results in this study, knowledge affects pregnant women's compliance in consuming Fe tablets. One of the efforts that can be done in increasing the knowledge of pregnant women is to provide counseling or counseling. It is very necessary to educate about anemia in pregnancy and the role of Fe tablets given to pregnant women to add insight and information for pregnant women. In addition to counseling, counseling also needs to be given to all pregnant women, not only pregnant women with anemia. This is in line with Prawirohardjo (2016) theory that one of the factors that influence compliance is knowledge. Knowledge of pregnant women will of course affect health behavior. The better the knowledge of pregnant women, the better their health behavior, and vice versa (Prawirohardjo, 2016).

Therefore, it is necessary to provide education related to the benefits of $\mathrm{Fe}$ tablets in pregnancy to continue to be carried out and monitoring pregnant women in consuming $\mathrm{Fe}$ tablets using a drug control book as well as control and evaluation related to the distribution of $\mathrm{Fe}$ tablets must be carried out on an ongoing basis in order to reduce the incidence of anemia in pregnant women. (Amanupunnyo, 2018). In addition, intensive health education during antenatal care visits about anemia in pregnancy and its prevention is expected to increase knowledge of pregnant women (Desi, 2015; Sukmawati, 2020).

The non-compliance of pregnant women in consuming $\mathrm{Fe}$ tablets is also caused by irregularity in taking Fe tablets, forgetting to take Fe tablets, not wanting to take $\mathrm{Fe}$ tablets because $\mathrm{Fe}$ tablets are difficult to swallow and lack of husband support to encourage pregnant women to consume Fe tablets. Therefore, the role of health workers is also needed in increasing awareness and counseling on nutrition and health to pregnant women, family members and the community (Utomo, 2015).

In addition to the knowledge factor, the side effects of the drug are mainly due to the bad taste and the forgetting factor which is also the reason for pregnant women not to comply with taking $\mathrm{Fe}$ tablets during pregnancy. There is a need for innovation or new breakthroughs so that pregnant women will be obedient to consuming Fe tablets on a regular basis, for example replacing $\mathrm{Fe}$ tablets with biscuits that have a better taste that contain Fe tablets without reducing the iron content. In addition, to overcome the forgetting factor, you can work with cadres to supervise pregnant women to consume $\mathrm{Fe}$ tablets, for example by SMS or chat reminders.

The SMS (Short Message Service) method can maximise the efficiency, effectiveness and equity of health services in improving health communication. This method does not require an internet connection, costs a bit expensive and can be done quickly and continuously. In addition, short message services can be used to monitor and provide information about the importance of taking iron tablets during pregnancy. This provides information easily so that users do not have to come to a health facility to get information about pregnancy. SMS reminder is a health promotion media in the form of SMS that provides information and promotion of health 
problems to the public with cellular numbers registered in the registration of cellular operators in Indonesia (Yani, et al, 2013).

This is in line with research conducted by Herlina, et al (2013) which stated that the application of the SMS reminder model as a health promotion medium in Astambul District, Banjar Regency has proven effective in conveying health information in increasing knowledge of pregnant women about complications and nutritional intake during pregnancy (Herlina, 2008). et al, 2013; Yani, et al, 2017).

\section{Effect Size}

Other factors that can cause a high bias in the effect size are language bias (English databases and journals are more likely to be searched and lead to research with statistically significant results), availability bias (selective in choosing research that is more accessible to researchers)., cost bias (selective in selecting freely available research or at low cost), familiar bias (selective in including research covering only a particular discipline), duplication bias (research with statistically significant results is more likely to be published in more than one discipline). times), and citation bias (where studies with statistically significant results are more likely to be cited by others and therefore easier to identify or find) (Retnawati, et al, 2018).

Based on the results of the analysis in this study, publication bias is caused by the inequality in the number of large and small samples. In addition, publication bias in this study is also caused by citation bias, where studies with significant results are easier to obtain than non-significant studies. The number of articles studied between significant and insignificant studies is not balanced, which is also the cause of this publication bias in research. this.

The impact of this publication bias is that the results or information produced are inaccurate because the published literature may not represent the research that has been done on a topic. Published literature (for example studies with significant positive results) tend to produce or show a stronger summary effect (overall effect size) than all studies (some have insignificant results; some are significant but negative; some are positively significant). considered or included (Card, 2012).

This study cannot overcome publication bias by comparing the effect size of formally published research with the effect size of unpublished research. This method requires access to unpublished research, and if you have that access, then there is no problem. However, this seems difficult to do.

\section{CONCLUSION}

After analysing using the RevMan application (Review Manager) 5.3 of 13 journal articles on the compliance variable, it was found that there was a relationship between adherence to consumption of $\mathrm{Fe}$ tablets with the incidence of anemia in pregnant women. The combined effect was significant if the $p$-value $<0.05$, which means that in this study, there was a significant relationship between adherence to Fe tablet consumption and the incidence of anemia in the pregnant mother.

\section{Acknowledgement: None}

\section{Conflict of Interest: None}

\section{Source of Funding: None}

\section{REFERENCES}

1. Anggraini, D.D. (2018). Predisposing Factors for Pregnant Women and Their Effects on Compliance with Consuming Iron $(\mathrm{Fe})$ Tablets and Anemia in Pregnant Women. Strada Scientific Journal of Health. Vol.7 No.1, pp: 9-22

2. Arisman, M.B. (2010). Textbook of Nutrition Science in the Cycle of Life. Edition-2. Jakarta: EGC

3. Ariyani, R. (2016). Factors Affecting the Occurrence of Anemia in Third Trimester Pregnant Women in the Mojolaban Health 
Center Work Area, Sukoharjo Regency. muhammadiyah Surakarta university

4. Astriana, W. (2017). The incidence of anemia in pregnant women in terms of parity and age. Journal of Health Sciences Aisyah, 2(2), 123-130.

5. Azam, U. (2012), Prayers and Remembrance Mustajab for Pregnant and Breastfeeding Mothers, Qultum Media, South Jakarta.

6. Bakta. (2007). Concise Clinical Hematology. Jakarta : EGC

7. Card, N. A. (2012). Applied meta-analysis for social science research. New York, NY: The Guilford Press.

8. Chalik, R \& Hidayati. (2019). Obedience of pregnant women in taking $\mathrm{Fe}$ tablets with the incidence of anemia at the Maccini Sawah Health Center Makassar City. Journal of Nursing Media: Makassar Health Polytechnic. Vol. 10 No. 01

9. Desi, A. M. Y, Apri, S \& Keisnawati. (2015). Factors Occurrence of Anemia in Primigravida Mothers in the Work Area of Pringsewu Health Center Lampung. Journal of Nursing. Vol. 6 No. 2

10. Fajrin, F.I. (2020). Compliance with Consumption of Iron (Fe) on the Incidence of Anemia in Pregnant Women. Journal of Health, Vol. 3 No. 4

11. Fakhriyah, et al. (2018). The Compliance of Pregnant Women Consuming Fe Tablets with the Incidence of Anemia in the Work Area of the Aranio Health Center. Jurkessia. Vol. VIII No. 2

12. Fitri, et al. 2015. Compliance with Iron Supplement Consumption and Its Effect on the Incidence of Anemia in Pregnant Women in Tangerang City. Journal of Bogor Agricultural University Vol.10 No. 3.

13. Galloway, R \& McGuire, J. (2013). Determinants of Compliance With Iron Supplementation: Supplies, Side Effects or Psychology

14. Guyton, A. C., \& Hall, J. E. (2011). Textbook of Medical Physiology Edition 11. Jakarta: EGC

15. Hackley, B., Kriebs, J.M., \& Rousseau, M.E. (2013). Textbook of Primary Health Care Midwives. Jakarta: EGC.

16. Herlina, S, Sanjaya, G.Y \& Emilia, O. (2013). Utilisation of Cellular Phone SMS Facility as a Media for Health Promotion for Pregnant Women in Remote Areas. Journal of Information Systems (OAJIS)
17. Indonesian Ministry of Health. (2007). Healthy Indonesia Indicators 2010 and Guidelines for Determining Healthy Provinces and Healthy Districts. Jakarta: The Indonesian Ministry of Health.

18. Indonesian Ministry of Health. (2009). Data and Information Research. Health Profile. Jakarta : Ministry of Health RI

19. Katmini \& Yunita, A. (2020). Factors Associated With Anemia Among Pregnant Women in Trimester III. Journal of Maternal and Child Health. 05 (03): 313320

20. Indonesian Ministry of Health. (2011). Health Profile of Indonesia 2010. Jakarta : Ministry of Health of the Republic of Indonesia

21. Khambalia, A.Z, et al. (2009). Periconceptional Iron Supplementation Does Not Reduce Anemia Or Improve Iron Status Among Pregnant Women In Rural Bangladesh. Am J Clin Nutr 90:1295-302.

22. Khomsan, A. (2004). Food and Nutrition for Health. Jakarta: PT Raja Grafindo Persada.

23. Malah, S.R.W, Montol, A.B, \& Sineke, J. (2016). The Relationship of Obedience of Pregnant Women in Consuming Iron $(\mathrm{Fe})$ Tablets with Hemoglobin ( $\mathrm{Hb}$ ) Levels in the Ranomut Health Center Area, Manado City. J. GIZIDO. Vol. 3 No. 2: 49-55

24. Manuaba, I.B. (2010). Obstetrics, Gynecology, and Family Planning. Jakarta: EGC

25. Miarti, N.K, et al. (2020). Analysis of Factors Associated with the Incidence of Anemia in Pregnant Women at Dana Health Center and Pasir Putih Health Center, Muna Regency. Midwifery Journal. Vol. 5, 13-18

26. Novitayanti, Nurlysis \& Afni, N. (2020). Identification of Causes of Anemia in Pregnant Women at Sungai Piring Public Health Center. Journal of Community Health (Journal of Community Health). 6(3):369-376

27. Nugroho, K.P., Merdekawati, W. \& Hekakaya, J.M. (2017). Relationship between Eating Behavior and Consumption of $\mathrm{Fe}$ Tablets with the Incidence of Anemia in Pregnant Women in Fakfak Regency, West Papua. Journal of Health ( JoH), 4(2), pp.92-99.

28. Obai, G, Odongo, P \& Wanyama, R. (2016). Prevalence of Anemia and Associated Risk Factors Among Pregnant Women Attending Antenatal Care In Gulu and Hoima Regional 
Hospitals in Uganda: A Cross-Sectional Study. BMC Pregnancy Childbirth 16, 1-7

29. Proverawati, A. (2013). Anemia And Pregnancy Anemia. Yogyakarta : Nuha Medika

30. Prawirohardjo, S. (2016). Midwifery. Jakarta: Bina Pustaka Sarwono Prawirohardjo.

31. Putri, S.I \& Sumarmi, S. (2013). Comparison of Consumption of Nutrients, Nutritional Status and Hemoglobin Levels of Bride in Coastal and Agricultural Areas, Probolinggo Regency. Indonesian Nutrition Media. 9, 72-77

32. Ratnasari, A.D., Gunawan, I.M.A \& Mursyid, A, (2017). The Relationship Between Obedience of Pregnant Women Consuming Fe Tablets, Intake of Fe, Protein and Vitamin $\mathrm{C}$ with the Incidence of Anemia in Kalasan Community Health Center. J.Nutr. Vol. 8 No. $1: 17-21$

33. Retnawati, H, et al. (2018). Introduction to Meta Analysis. Yogyakarta : Parama Publishing

34. Romlah \& Anjelin, S. (2020). Consumption of Iron Tablets on Hemoglobin Levels in Second Trimester Pregnant Women. Palembang Polytechnic Health Journal (JPP). Vol. 15 No. 1

35. Ruwaydah \& Nurmisi. (2019). Relationship of Adequacy of Fe Consumption, Diet and Size of Lila with Anemia of Pregnant Women at Simpang Kawat Health Center Jambi City. Journal of Public Health Materials. Vol. 3 No. 2Study, P. 2014. Nutrition I, Medicine F, Diponegoro U. Journal of Nutrition College, Vol.3 No.4 0310.

36. Sari, A \& Romlah. (2019). Factors Associated with the Occurrence of Anemia in Third Trimester Pregnant Women. Journal of Telenursing (JOTING). Vol.1 No. 2

37. Sepduwiana, H \& Sutrianingsih, R.N.S. (2017). Relationship between Pregnancy Distance and Compliance with Taking Fe Tablets with the Incidence of Anemia in Pregnant Women in the Work Area of Rambah Samo Health Center 1. Journal of Maternity and Neonatal. 2 (4)

38. Sinaga, R.J \& Hasanah, N. (2019). Determinants of the Incidence of Anemia in Pregnant Women at Tunggakjati Public Health Center, West Karawang District, 2019. Journal of Public Health. Vol. 3, No.2
39. Sophia. (2009). Relationship between adherence to iron tablets with the incidence of anemia in pregnant women in the Danurejan II Health Center Work Area, Yogyakarta City in 2009. Yogyakarta: Ministry of Health RI Department of Nutrition

40. Sudasiyah. (2017). Factors Associated with Anemia in Third Trimester Pregnant Women at Bumi Emas Health Center, East Lampung Regency in 2016. Journal of Health "Akbid Wira Buana". Vol.1 No.1

41. Sukmawati, et al. (2020). Pregnancy Anemia And Its Affecting Factors: Correlation Study. Journal of Health Bakti Tunas Husada: Journal of Nursing, Health Analyst and Pharmacy. Vol. 21 No. 1

42. Tanziha, I, et al. (2016). Risk Factors for Anemia in Pregnant Women in Indonesia. J. Food Nutrition. 11(2):143-152

43. Tarwoto \& Wasnidar. (2007). Pocket book of anemia in pregnant women and management concepts. Jakarta: Trans Info Media. 2007.

44. Triyani, S \& Purbowati, N. (2016). Compliance with Fe Tablet Consumption in Preventing Iron Nutrient Anemia in Pregnant Women in the Health Center Area, Central Jakarta District. Journal of Health Science and Technology. Vol. 3 No. 2

45. Utomo, A.P.W, Nurdiati, D.S \& Padmawati, R.S. (2015). Low Iron Intake and Compliance with Taking Iron Tablets Are Associated with the Incidence of Anemia in Pregnant Women in the Working Area of Puskesmas I Kembaran, Bnayumas. Indonesian Journal of Nutrition and Dietetics. Vol. 3 No. 1

46. Wuwuh, S., Sri, R., \& Krisdiana, W. (2016). The Effect of Cadre Assistance on Pregnant Women on Compliance with Taking $\mathrm{Fe}$ Tablets. Scientific Journal of Midwifery. Vol. 1, No.3

47. World Health Organization. (2015). The Global Prevalence of Anemia in 2011. Geneva: World Health Organization.

48. Yani, et al. (2012). "The Effect of SMS Reminder on Pregnant Mother Behavior Consuming Fe Tablets. The Effect of SMS Reminder on Pregnant Mother Behavior Consuming Iron Tablets.": 12-20.

49. Yanti, D.E. (2016). The Relationship between Compliance with $\mathrm{Fe}$ Tablet Consumption and the Incidence of Anemia in Third Trimester Pregnant Women at the 
Bernung Public Health Center, Pesawaran Regency 2016. World Health Journal. Vol. 5 No. 3

50. Zijp, I.M, Korver, O \& Tijburg L.B. (2000). Effect of Tea and Other Dietary Factors on Iron Absorption. Critical Review in Food Sciences and Nutrition 40(5):372-398.
How to cite this article: Muti'ah Ma'rifati Ilma, Panghiyangani R, Kania N et.al. Meta-analysis: the relationship of $\mathrm{Fe}$ tablet consumption adherence and anemia prevalence in pregnant women. International Journal of Science \& Healthcare Research. 2021; 6(4): 23-35. DOI: https://doi.org/10.52403/ijshr.20211005 